\title{
EFFECTIVENESS OF ONLINE VS. TRADITIONAL CLASSROOM TEACHING FOR UNDERGRADUATE MEDICAL STUDENTS: A STUDENT'S PERSPECTIVE
}

\author{
AYESHA SHAUKAT, GHAZANFAR ALI, FARHEEN HASSAN, MUHAMMAD NAEEM ABBAS, \\ MUHAMMAD ASAD SALEEM \\ Department of General Surgery, King Edward Medical University, Lahore, Pakistan
}

\begin{abstract}
Objective: To find effectiveness between online and traditional classroom teaching methods among final year class of MBBS.

Methods: An observational study conducted at King Edward Medical University Lahore in April 2020 among final year class of MBBS. Two Likert-scale questionnaires generated on Google Docs after taking approval from university's ethical committee. Informed consent taken and all students of final year class of MBBS, of both genders were included. Univariate analysis done taking preference of teaching method as primary objective. P value $\leq 0.05$ considered significant. Data was analyzed using SPSS v20.

Results: Three hundred and three $(n=303)$ students responded to traditional model and three hundred and ten $(n=310)$ responded to online. Overall, mean value of student preference for traditional mode of teaching was higher than online (3.62 vs. 3.09). Univariate analysis showed, in traditional mode of teaching students felt more concentrated during lectures $(\mathrm{p}<.001)$ and had more interclass interaction ( $\mathrm{p}<.001)$. Student felt online mode of teaching more effective $(\mathrm{p}=0.02)$ and found it more feasible to respond to class tests $(\mathrm{p}=0.01)$. However, both methods were significant regarding increasing productivity of students $(\mathrm{p}<.001, \mathrm{p}<.001)$, non-complex $(\mathrm{p}=0.01, \mathrm{p}=0.01)$ and enjoyable $(\mathrm{p}<.001, \mathrm{p}=0.01)$

Conclusion: Due to Covid-19's high number, interruptions in medical education are to happen worldwide. Arrangements need to be made whereby students can retain clinical skills and knowledge. Overall, traditional learning was more preferred among students in our study, so we need to be more careful in every way depending on online courses unless system readiness, skillful testing, a rigorous feedback system and a mass strategy can lead to this path in future.
\end{abstract}

Keywords: Covid-19, pandemic, productivity of students.

How to cite this article: Shoukat A, Ali G, Hassan F, Abbas MN, Saleem MA. Effectiveness of online vs. Traditional classroom teaching for undergraduate medical students: a student's perspective. Pak Postgrad Med J 2020;31(1): 32-36

This is an Open Access article distributed under the terms of the Creative Commons Attribution License (http://creativecommons.org/licenses/by/3.0), which permits unrestricted use, distribution, and reproduction in any medium, provided the original work is properly cited.

DOI: HTTPS//DOI.ORG/10.51642/ppmj. v31i01.368

Correspondence to: Ghazanfar Ali

Department of General Surgery, King Edward Medical University, Lahore, Pakistan.

E-mail:dr.gznfr@gmail.com

\section{INTRODUCTION}

Effective medical education requires versatility, energy and dedication in the presence of a busy healthcare delivery background. ${ }^{1}$ One of most approved factor for evaluating effective teaching is indeed the proportion of learning process among students. ${ }^{2}$ Correlations between effective learning at institution and student benefits have really been increasingly recognized, both developmentally in general and especially at the course level ${ }^{3}$. Various studies have reported with a viewpoint that new medical graduate students are not ready for their responsibilities as healthcare providers ${ }^{4}$.

Traditional learning means that the teacher is the regulator of the educational setting. The teacher performs the character of trainer (in the form of lectures) and judgment-maker (in terms of curriculum material and specific results ${ }^{5}$. They consider students to have 'knowledge gaps' that need to be covered with knowledge 5 . In brief, the traditional teacher views that it is the instructor who creates learning to take place. ${ }^{5}$ Given the criticism this school model has faced from 
others, the classroom led by one instructor in the school system has unique benefits that illustrate the explanations for its universal appeal ${ }^{6}$. Most students thrive and prosper in this system of teaching. ${ }^{6}$

Web-based approaches for medical training may be of significant help to the goal of better health and wellbeing and quality education, particularly in low-income countries ${ }^{7}$. There is little sound research data on the impact of online learning on medical education in resource-stricken nations, including its capabilities and limitations ${ }^{8}$. Appropriate and efficient as well as standard "technology-enhanced learning" development models and high quality studies that describe this method for healthcare workers are still needed ${ }^{9}$. Such reports also struggle to include adequate information to endorse the transferability or immediate potential of "technology-enhanced learning" systems for health care education?.

Ranges of studies exist in the literature about online mode of teaching which document implementation of technology using online, web-based and flipped mode of teaching within medical and health care educational approaches. However, research undertaken in resourcelimited countries stress the need to examine these learning modes before their introduction ${ }^{7,8}$, and 9 . Our university has started online classes during Covid-19 lockdown for MBBS students. The objective of study was to compare traditional vs. online ways of learning in Pakistan; to see students' perspective regarding both ways of teaching.

\section{METHODS}

It was a single-institution comparative study conducted at King Edward Medical University Lahore during April 2020. We selected all students of final year MBBS as our research participants after taking informed consent. Two questionnaires each containing twenty questions generated on Google Docs and circulated in their classroom through their email IDs. The questionnaire was having likert-scale model (Strongly Disagree $=01$, Disagree $=02$, Neutral $=03$, Agree $=04$ and Strongly Agree=05). Main objective was to check their preference between newly started online mode vs. traditional mode of learning, which they have been taught previously, and review reasons behind it. Inclusions criteria were all students of final year class of MBBS currently enrolled in university, of both gender, have attend frequent online and traditional teaching sessions. Exclusion criteria were students of other classes of MBBS and those who did not respond to questionnaire. After permission from the concerned hospital authorities, ethical committee and fulfilling the inclusion and exclusion criteria for all the patients, questionnaire was collected after getting response.

Data was analyzed using SPSS v20. All qualitative variables in questionnaire were, presented in form of mean and standard deviation in their respective likenchart scale. Univariate analysis done taking preference as dependent variable. $\mathrm{P}$ value $\leq 0.05$ considered significant.

\section{RESULTS}

Total number of students who responded to our questionnaire for traditional way of teaching were three hundred and three $(n=303)$ and those to online mode were three hundred and ten $(n=310)$. The mean values along with standard deviation for all questions shown in the Table (1). For proper interpretation of data, two questions numbers 16 and 18 reversed in data interpretation, as they were negative leading questions. Paired $\mathrm{T}$ test values taking alpha values $\leq 0.05$ as significant shown in (Table 1.)

Students responded to some questions with preference to both style of learning and some to only single one. Overall mean values of traditional was higher than online mode of learning (3.62 vs. 3.09). (Fig.1)

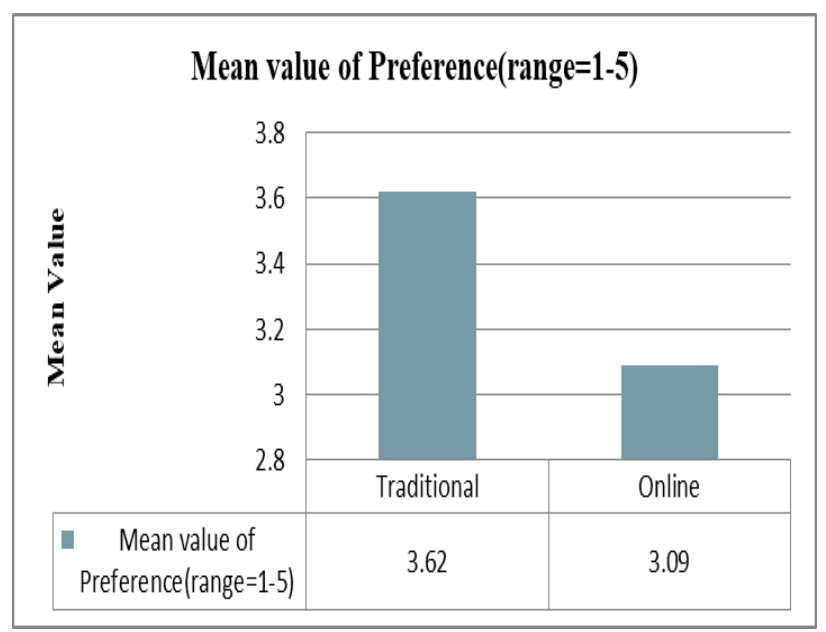

Fig 1. Overall, mean value of preference for both teaching methods.

Univariate analysis of variables showing their relation with preference of teaching (Question 20) shown in (Table 2). Significant factors favoring traditional mode of teaching were more concentration during lectures $(\mathrm{p}<.001)$ and more interclass interaction $(\mathrm{p}<.001)$. Factors favoring online mode of teaching were, effective way of teaching $(\mathrm{p}=0.02)$ and feasibility of responding to class test easily $(\mathrm{p}<.001)$. Both methods were preferred regarding increasing productivity of 
students $(\mathrm{p}<.001, \mathrm{p}<.001)$, less complex way of teaching $(\mathrm{p}=0.01, \mathrm{p}=0.01)$ and enjoyable methods $(\mathrm{p}<0.001, \mathrm{p}=0.01)$.

Table 1: Descriptive Analysis of variables showing response of students and preference to model of learning

\begin{tabular}{|c|c|c|c|c|}
\hline QUESTIONS & $\begin{array}{l}\text { Traditional vs. } \\
\text { Online }\end{array}$ & $\begin{array}{c}\text { Mean } \\
\text { (Range1-5) }\end{array}$ & St. Deviation & $\begin{array}{l}\text { Paired Sample T } \\
\text { test } p=\leq 0.05\end{array}$ \\
\hline $\begin{array}{l}\text { It is effective in explaining the objectives of the } \\
\text { assigned topic. }\end{array}$ & $\begin{array}{l}\text { Traditional } \\
\text { Online }\end{array}$ & $\begin{array}{l}4.03 \\
3.61\end{array}$ & $\begin{array}{l}0.86 \\
0.96\end{array}$ & $\begin{array}{l}<.001 \\
<.001\end{array}$ \\
\hline $\begin{array}{l}\text { The information given in the lecture helped me } \\
\text { resolve my queries }\end{array}$ & $\begin{array}{l}\text { Traditional } \\
\text { Online }\end{array}$ & $\begin{array}{l}3.90 \\
3.51\end{array}$ & $\begin{array}{l}0.94 \\
0.95\end{array}$ & $\begin{array}{l}<.001 \\
<.001\end{array}$ \\
\hline $\begin{array}{l}\text { My facilitator uses appropriate aids that helped me } \\
\text { learn }\end{array}$ & $\begin{array}{l}\text { Traditional } \\
\text { Online }\end{array}$ & $\begin{array}{l}3.95 \\
3.64\end{array}$ & $\begin{array}{l}0.87 \\
0.91\end{array}$ & $\begin{array}{l}<.001 \\
<.001\end{array}$ \\
\hline $\begin{array}{l}\text { My facilitator helps me learn in an organized, } \\
\text { coherent manner }\end{array}$ & $\begin{array}{l}\text { Traditional } \\
\text { Online }\end{array}$ & $\begin{array}{l}3.87 \\
3.70\end{array}$ & $\begin{array}{l}0.88 \\
0.89\end{array}$ & $\begin{array}{l}<.001 \\
<.001\end{array}$ \\
\hline It is easy to ask questions from the facilitator & $\begin{array}{l}\text { Traditional } \\
\text { Online }\end{array}$ & $\begin{array}{l}3.64 \\
3.18\end{array}$ & $\begin{array}{l}1.20 \\
1.23\end{array}$ & $\begin{array}{l}0.79 \\
0.26\end{array}$ \\
\hline The environment is comfortable & $\begin{array}{l}\text { Traditional } \\
\text { Online }\end{array}$ & $\begin{array}{l}3.24 \\
4.07\end{array}$ & $\begin{array}{l}1.19 \\
0.95\end{array}$ & $\begin{array}{l}<.001 \\
<.001\end{array}$ \\
\hline It is an enjoyable experience. & $\begin{array}{l}\text { Traditional } \\
\text { Online }\end{array}$ & $\begin{array}{l}3.51 \\
3.64\end{array}$ & $\begin{array}{l}1.17 \\
1.22\end{array}$ & $\begin{array}{l}0.08 \\
<.001\end{array}$ \\
\hline It was easier to concentrate and avoid distractions. & $\begin{array}{l}\text { Traditional } \\
\text { Online }\end{array}$ & $\begin{array}{l}2.96 \\
3.45\end{array}$ & $\begin{array}{l}1.26 \\
1.32\end{array}$ & $\begin{array}{l}<.001 \\
<.001\end{array}$ \\
\hline $\begin{array}{l}\text { There was a feeling of one to one contact with the } \\
\text { facilitator. }\end{array}$ & $\begin{array}{l}\text { Traditional } \\
\text { Online }\end{array}$ & $\begin{array}{l}3.28 \\
3.05\end{array}$ & $\begin{array}{l}1.29 \\
1.24\end{array}$ & $\begin{array}{l}<.001 \\
0.64\end{array}$ \\
\hline It is more effective for inter class interaction & $\begin{array}{l}\text { Traditional } \\
\text { Online }\end{array}$ & $\begin{array}{l}3.86 \\
2.61\end{array}$ & $\begin{array}{l}1.12 \\
1.18\end{array}$ & $\begin{array}{l}<.001 \\
<.001\end{array}$ \\
\hline It is easier to maintain class discipline & $\begin{array}{l}\text { Traditional } \\
\text { Online }\end{array}$ & $\begin{array}{l}2.86 \\
3.82\end{array}$ & $\begin{array}{l}1.23 \\
1.03\end{array}$ & $\begin{array}{l}<.001 \\
<.001\end{array}$ \\
\hline $\begin{array}{l}\text { This method of teaching is better for meeting } \\
\text { working deadlines, assignment }\end{array}$ & $\begin{array}{l}\text { Traditional } \\
\text { Online }\end{array}$ & $\begin{array}{l}3.21 \\
3.91\end{array}$ & $\begin{array}{l}1.21 \\
1.07\end{array}$ & $\begin{array}{l}<.001 \\
<.001\end{array}$ \\
\hline The facilitator responds to my questions & $\begin{array}{l}\text { Traditional } \\
\text { Online }\end{array}$ & $\begin{array}{l}4.15 \\
3.99\end{array}$ & $\begin{array}{l}0.79 \\
0.81\end{array}$ & $\begin{array}{l}<.001 \\
<.001\end{array}$ \\
\hline The course material is covered well. & $\begin{array}{l}\text { Traditional } \\
\text { Online }\end{array}$ & $\begin{array}{l}4.01 \\
3.59\end{array}$ & $\begin{array}{l}0.93 \\
1.11\end{array}$ & $\begin{array}{l}<.001 \\
<.001\end{array}$ \\
\hline This method is cost effective. & $\begin{array}{l}\text { Traditional } \\
\text { Online }\end{array}$ & $\begin{array}{l}3.18 \\
3.75\end{array}$ & $\begin{array}{l}1.15 \\
1.16\end{array}$ & $\begin{array}{l}<.001 \\
<.001\end{array}$ \\
\hline It is less complex way of learning & $\begin{array}{l}\text { Traditional } \\
\text { Online }\end{array}$ & $\begin{array}{l}2.54 \\
3.10\end{array}$ & $\begin{array}{l}1.09 \\
1.21\end{array}$ & $\begin{array}{l}<.001 \\
0.93\end{array}$ \\
\hline $\begin{array}{l}\text { It provides more productivity of students } \\
\text { regarding their work output }\end{array}$ & $\begin{array}{l}\text { Traditional } \\
\text { Online }\end{array}$ & $\begin{array}{l}3.49 \\
3.18\end{array}$ & $\begin{array}{l}1.15 \\
1.22\end{array}$ & $\begin{array}{l}0.05 \\
0.11\end{array}$ \\
\hline This mode of learning is less time consuming. & $\begin{array}{l}\text { Traditional } \\
\text { Online }\end{array}$ & $\begin{array}{l}3.39 \\
2.57\end{array}$ & $\begin{array}{l}1.20 \\
1.15\end{array}$ & $\begin{array}{l}0.05 \\
<.001\end{array}$ \\
\hline It is easier to respond to class tests. & $\begin{array}{l}\text { Traditional } \\
\text { Online }\end{array}$ & $\begin{array}{l}3.42 \\
3.97\end{array}$ & $\begin{array}{l}1.15 \\
1.05\end{array}$ & $\begin{array}{l}<.001 \\
<.001\end{array}$ \\
\hline I would prefer this method for lectures & $\begin{array}{l}\text { Traditional } \\
\text { Online }\end{array}$ & $\begin{array}{l}3.62 \\
3.09\end{array}$ & $\begin{array}{l}1.34 \\
1.39\end{array}$ & ----- \\
\hline
\end{tabular}




\section{DISCUSSION}

Medical students who grew up in this modern age are beginning to experience one of the most substantial changes in medical education ${ }^{10}$. Teaching modes are always evolving in medical field, traditional mode of teaching being prevalent in our country. This research analyzed to what degree student prefer their teaching method (traditional vs. online component), we also examined possible explanations for their selection.

Online method is a more efficient method of learning ${ }^{11}$. However, compared to their more traditional classroom counterparts, they may be less likely to participate in cohesive learning, student-faculty interactions and debates with various others ${ }^{12}$. Our study showed student preferred online method because it was effective and was easier to respond to class tests. $L o C K$ et al. in his study showed recent trend towards flipped class model or blended learning ${ }^{13}$. At the test and optional assignment, the students in the flipped class done much better than the students who were taught online impartial research courses ${ }^{13}$. Khasawneh $R$ et al. recommended the subtle but meaningful body of research that online methods are not just a uniformly effective learning opportunity and that their application in existing curricula takes extensive assessment ${ }^{14}$ and our study results suggest the same.

Hurlbut $A R$ in his study showed traditional method is more preferred because it provides more interclass interaction, an enjoyable experience and provides more concentrated environment to students. Also, traditional class students reported stronger communication with classmates than those in the online class ${ }^{15}$. Learners in the traditional class noted in-class interactions like facetime with the teacher, involvement in hands-on activities, group discussion and small group activities as some of the most useful learning styles, which led to success ${ }^{15}$. Keis $O$ et al. demonstrated that learners did not observe any organized face-to - face interactions in online section ${ }^{16}$. The same trend observed in our study as student preferred traditional mode regarding more inter class interaction. Future research may profit from investigating peer networking and cooperation in online contexts that are both synchronous and asynchronous relative to conventional learning forms ${ }^{17}$

The results of the questionnaire suggest that students respond to both course modes of delivery adhering to their own desired understanding of learning found both enjoyable. Owing to the peculiar layout and confounding of each research focusing on the organization, implemented e-modules, evaluations used, and target population of respondents; it is difficult to compare our information directly with several other research findings. However, it really does emphasize the importance of analyzing online vs. traditional approach across each setting to evaluate the effectiveness of each of them.

Table 2. Univariate analysis of variables showing their relation with preference of teaching.

\begin{tabular}{lcc}
\hline Variables & $\begin{array}{c}\text { Univariate } \\
\text { Analysis of } \\
\text { Traditional } \\
\text { Method } \\
(\mathrm{p}=\leq 0.05)\end{array}$ & $\begin{array}{c}\text { Univariate } \\
\text { Analysis } \\
\text { of Online } \\
\text { Method } \\
(\mathrm{p}=\leq 0.05)\end{array}$ \\
\hline Effectiveness & 0.10 & 0.02 \\
Queries Solution & 0.70 & 0.06 \\
Lecture Aids & 0.08 & 0.96 \\
Organized Manner & 0.05 & 0.38 \\
Ease of Asking Queries & 0.60 & 0.47 \\
Comfortable Environment & 0.81 & 0.63 \\
Enjoyable & $<.001$ & 0.01 \\
Concentration on Lecture & $<.001$ & 0.22 \\
Face to face Interaction & 0.63 & 0.39 \\
Interclass Interaction & $<.001$ & 0.06 \\
Discipline in Class & 0.53 & 0.11 \\
Meeting Work Deadlines & 0.62 & 0.22 \\
Facilitator Response & 0.71 & 0.95 \\
Course material Coverage & 0.45 & 0.89 \\
Cost effectiveness & 0.63 & 0.54 \\
Lesser Complexity & 0.01 & 0.01 \\
Productivity of Method & $<.001$ & $<0.001$ \\
Time Consuming & 0.64 & 0.95 \\
Class Tests Easily Done & 0.07 & 0.01 \\
\hline & &
\end{tabular}

\section{CONCLUSION}

Since health services have been squeezed further with COVID-19's high number, interruptions in medical education are sure to happen worldwide. Arrangements need to be made whereby students can retain clinical skills and knowledge. Traditional learning was more preferred among students in our study, so we need to be more careful in every way, depending on online courses, unless system readiness, skillful testing, a rigorous feedback system, and a mass strategy can lead to this path. Both systems have their own pros and cons but future lies in more blended approach hence universities should show more readiness in their approaches to this system. It would not only be necessary to address the medical education challenge successfully during this present situation, but it would also serve to build the groundwork for learning in natural disasters and even beyond.

\section{CONFLICT OF INTEREST}

Authors declared no conflict of interest. 


\section{DISCLOSURE}

Authors have nothing to disclose

\section{FUNDING}

No funding taken from any source

\section{PARTICIPANTS' CONSENT}

Informed consents obtained from all individual participants included in the study.

\section{ETHICAL APPROVAL}

The study was approved from Ethical Review Committee of King Edward Medical University, Lahore, Pakistan, vide reference No. 359/RC/KEMU dated May 19, 2020.

\section{REFERENCES}

1. Vaughn L, Baker R. Teaching in the medical setting: balancing teaching styles, learning styles and teaching methods. Medical teacher. 2001;23(6):610-612.

2. Wickramasinghe $S$, Upeksha GN. Innovative and interactive teaching methods for improving learning quality in higher education.

3. Stupnisky RH, BrckaLorenz A, Yuhas B, Guay F. Faculty members' motivation for teaching and best practices: Testing a model based on self-determination theory across institution types. Contemp. Educ. Psychol. 2018;53:15-26.

4. Monrouxe LV, Grundy L, Mann M, John Z, Panagoulas E, Bullock A et al. How prepared are UK medical graduates for practice? A rapid review of the literature 2009-2014. BMJ open. 2017;7(1):e013656.

5. Novak JD. Learning, creating, and using knowledge: Concept maps as facilitative tools in schools and corporations. Routledge; 2010.

6. Huson J. The Advantages of Traditional Schools [Internet]. https://www.seattlepi.com/. 2016 [cited 6 June 2020]. Available from: https://education.seattlepi. com/advantages-traditional-schools-2140.html

7. Liu Q, Peng W, Zhang F, Hu R, Li Y, Yan W. The effectiveness of blended learning in health professions: systematic review and meta-analysis. J. Med. Internet Res. 2016;18(1):e2.
8. Frehywot S, Vovides Y, Talib Z, Mikhail N, Ross H, Wohltjen $\mathrm{H}$ et al. E-learning in medical education in resource constrained low-and middle-income countries. Hum. Resour. Health. 2013;11(1):4.

9. Nicoll P, MacRury S, Van Woerden HC, Smyth K. Evaluation of technology-enhanced learning programs for health care professionals: systematic review. J Med Internet Res. 2018;20(4):e131.

10. Tang B, Coret A, Qureshi A, Barron H, Ayala AP, Law M. Online lectures in undergraduate medical education: scoping review. JMIR Med. 2018;4(1):e11.

11. O'Doherty D, Dromey M, Lougheed J, Hannigan A, Last J, McGrath D. Barriers and solutions to online learning in medical education-an integrative review. BMC Med. Educ. 2018;18(1):130.

12. Dumford AD, Miller AL. Online learning in higher education: exploring advantages and disadvantages for engagement. $J$ Comput High Educ. 2018;30(3):452-465.

13. Lo CK, Hew KF. A comparison of flipped learning with gamification, traditional learning, and online independent study: the effects on students' mathematics achievement and cognitive engagement Interact. Learn. Environ. 2018;13:1-8.

14. Khasawneh R, Simonsen K, Snowden J, Higgins J, Beck G. The effectiveness of e-learning in pediatric medical student education. Med Educ. Online.;21(1):29516.

15. Hurlbut AR. Online vs. traditional learning in teacher education: a comparison of student progress. Am J Distance Educ. 2018;32(4):248-266.

16. Keis O, Grab C, Schneider A, Öchsner W. Online or face-to-face instruction? A qualitative study on the electrocardiogram course at the University of Ulm to examine why students choose a particular format. $B M C$ Med. Educ. 2017;17(1):194.

17. Daniel MC, Schumacher G, Stelter N, Riley C. Student perception of online learning in ESL bilingual teacher preparation. Univers. J. Educ. Res. 2016;4(3):561-569.

\section{AUTHORS' CONTRIBUTION}

AS: Concept, Design, Manuscript Writing, Proof Reading

GA, FH, MNA, MAS: Data Collection, Design, Manuscript Writing 